Old Dominion University

ODU Digital Commons

Physics Faculty Publications

Physics

$1-2020$

Question 1: Car Flip; Question 2: A Mole of People

Larry Weinstein

Follow this and additional works at: https://digitalcommons.odu.edu/physics_fac_pubs

Part of the Physics Commons 


\section{Question 1: Car flip; Question 2: A mole of people}

Larry Weinstein

Citation: The Physics Teacher 58, 69 (2020); doi: 10.1119/1.5141981

View online: https://doi.org/10.1119/1.5141981

View Table of Contents: https://aapt.scitation.org/toc/pte/58/1

Published by the American Association of Physics Teachers

\section{ARTICLES YOU MAY BE INTERESTED IN}

Solutions for Fermi Questions, January 2020: Question 1: Car flip; Question 2: A mole of people The Physics Teacher 58, A69 (2020); https://doi.org/10.1119/1.5141955

January jiggle

The Physics Teacher 58, 70 (2020); https://doi.org/10.1119/1.5141982

SHOCK WAVE

The Physics Teacher 58, 4 (2020); https://doi.org/10.1119/1.5141957

Solution to the October, 2019 Challenge Up and Away...

The Physics Teacher 58, A70 (2020); https://doi.org/10.1119/1.5141956

Figuring Physics December 2019 Solution

The Physics Teacher 58, 71 (2020); https://doi.org/10.1119/1.5141983

Demonstrating the Cosmic Distance Ladder with Cepheids

The Physics Teacher 58, 6 (2020); https://doi.org/10.1119/1.5141960

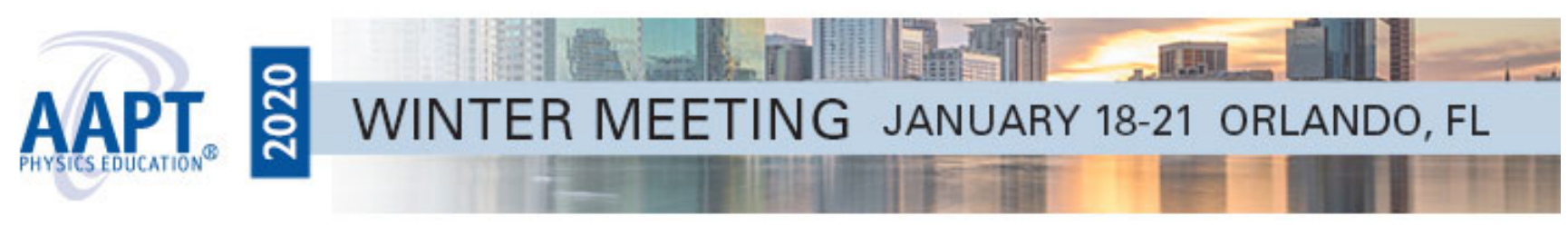


Table I. Glass marbles.

\begin{tabular}{|c|c|c|c|c|c|}
\hline $\begin{array}{l}\text { Number of } \\
\text { lab group }\end{array}$ & $\begin{array}{l}\text { Initial } \\
\text { volume of } \\
\text { water } \\
\text { [mL] }\end{array}$ & $\begin{array}{c}\text { Number of } \\
\text { marbles }\end{array}$ & $\begin{array}{c}\text { Final } \\
\text { volume } \\
\text { of water } \\
\text { [mL] }\end{array}$ & $\begin{array}{l}\text { Total volume } \\
\text { of marbles } \\
\text { using vol- } \\
\text { ume formula } \\
{\left[\mathrm{cm}^{3}\right]}\end{array}$ & $\begin{array}{l}\text { Total volume } \\
\text { of marbles } \\
\text { using gradu- } \\
\text { ated cylinder } \\
\text { [mL] }\end{array}$ \\
\hline 1 & 59 & 3 & 65 & 6.03 & 6 \\
\hline 2 & 61 & 5 & 71 & 9.95 & 10 \\
\hline 3 & 55 & 7 & 69 & 14.21 & 14 \\
\hline 4 & 60 & 9 & 78 & 18.09 & 18 \\
\hline 5 & 65 & 11 & 87 & 22.00 & 22 \\
\hline 6 & 59 & 13 & 85 & 25.48 & 26 \\
\hline
\end{tabular}

b) Analyze and interpret data to determine similarities and differences in findings. (MS-ETS1-3)

c) Develop a model to predict and/or describe phenomena. (MS-PS1-1), (MS-PS1-4)

d) Convert among different-sized standard measurement units within a given measurement system (Common Core 5.MD.A.1)

e) Choose a level of accuracy appropriate to limitations on measurement when reporting quantities. (HSESS2-6, HS-PS1-6, 7)

f) Each pure substance has characteristic physical and chemical properties (for any bulk quantity under given conditions) that can be used to identify it. https://ngss.nsta.org/DisciplinaryCoreIdeas.aspx?id $=1 \&$ detail $I D=50$

g) Examples of models can be physical, graphical, or conceptual. (MS-ESS1-2)

Since the ratio of the volume in $\mathrm{mL}$ over the volume in $\mathrm{cm}^{3}$ is equal to 1.0 , then they are equivalent in numerical value. That is, $V(\mathrm{~mL})=V\left(\mathrm{~cm}^{3}\right)$.

From this the students have shown that the volume in $\mathrm{mL}$ is equal to the volume in $\mathrm{cm}^{3}$. Using similar procedures, students can find conversion factors between other quantities (e.g., grams and ounces, feet and inches, centimeters and millimeters, etc.).

Any teacher who would like an electronic copy of the Student Activity Sheet and the Teacher's Notes we use, please send an email request to the authors, nelsonjh@ix.netcom. com.

\section{References}

1. In the metric system, Celsius and kelvins. In the "English" system, feet and inches.

2. The activity also addresses several Next Generation Science \& Engineering Standards.

a) Construct, analyze, and/or interpret graphical displays of data and/or large data sets to identify linear and nonlinear relationships. See https://ngss.nsta.org/Practices.aspx?id=5\&exampleid $=422$. h) Know relative sizes of measurement units within one system of units. (Common core 4.md.a.1)

i) Construct and interpret graphical displays of data to describe the relationships. (MS-PS3-1.)

j) Describe and graph quantities such as area and volume to address scientific questions. (5-ESS2-2)

3. A convenient source of identical glass marbles is a Chinese checkers game.

4. For a review of a graduate cylinder, see https://en.wikipedia. org/wiki/Graduated_cylinder. A nice worksheet for students can be found at "Volume Measurements with a Graduated Cylinder," https://web.archive.org/web/20160216103647/http:// www.dlsu.edu.ph/academics/colleges/cos/physics/_pdf/sig-fig5-volume-measurements.pdf.

5. This process essentially morphs from mathematics (equation of a straight line) to science (equation for data used). For a more complete description of the four-step analysis process, see Jane Nelson, "Why multiply by g?" Phys. Teach. 50, 123 (March 2012); Jim and Jane Nelson, "Buoyancy can-can," Phys. Teach. 53, 279 (May 2015); and Jim and Jane Nelson, "A new look at an old activity," Phys. Teach. 55, 546 (Dec. 2017).

\section{Fermi Questions}

Larry Weinstein, Column Editor Old Dominion University, Norfolk, VA 23529; weinstein@odu.edu

\section{Question 1: Car flip}

At what speed will a car flip over when it slides sideways into a curb? (Thanks to Reynier Cruz-Torres of MIT for suggesting the question.)

\section{Question 2: A mole of people}

How much is a mole of people? Consider mass, area, power, and food requirements. Make appropriately silly comparisons. (Thanks to Bryan Suits of Michigan Technical University for suggesting the problem.)

Look for the answers online at tpt.aapt.org under "Browse," at the very end of the current issue.

Question suggestions are always welcome!

For more Fermi questions and answers, see Guesstimation 2.0: Solving Today's Problems on the Back of a Napkin, by Lawrence Weinstein (Princeton University Press, 2012). 